\title{
MORFOLOGI TANAH INCEPTISOL SETELAH DILAKUKAN PENAMBANGAN UNTUK BAHAN BAKU PEMBUATAN BATU BATA
}

\section{Morphology of Inceptisol Soil after Mining for Brick Making Material}

\author{
Efriandi* \\ Badan Penelitian dan Pengembangan Daerah Provinsi Sumatera Selatan, Jalan Demang Lebar Daun No. \\ 4864, Palembang-Sumatera Selatan, Telp.374456; Fax.350077 \\ *Penulis korespondensi: efri_syarfa@gmail.com
}

\begin{abstract}
The purpose of this study was to observe changes in soil morphology after mining for the brick industry. The study was carried out by observing four soil profiles. i.e. (1) soils that have never been mined (control); (2) soils that have been mined and left more than 10 years, (3) soils that have been mined and left for \pm 5 years, and (4) soils that have been mined and left between 1-3 years. The method used in this study was the observation of a complete profile (cross-section of soil) which aimed to collect primary data directly through field observations and the description of individual soil horizons. The implementation of this research consisted of three stages, i.e. soil survey, soil profile description, and collection of soil samples from soils that have never been mined and that have been mined for years. Results of this study showed changes in soil morphology after the soils were mined for years, i.e. yellowish-brown colour, granular structure, loose consistency, no rooting zone, and abrupt horizons. The Inceptisol soils that have been mined for brick making materials experienced changes of morphology and soil properties. Further studies on land rehabilitation technique need to be carried out for consideration in restoring post-mining lands.
\end{abstract}

Keyword: brick material; Inceptisol; mining; soil morphology

\section{Pendahuluan}

Sumber daya lahan merupakan suatu massa yang kita manfaatkan untuk berusaha dan untuk kehidupan. Lahan ini bukannya milik kita, tetapi lebih tepat sebagai lahan pinjaman dari anak cucu kita. Oleh karena itu perlu kita kelola secara baik dan benar, sesuai dengan potensinya. Selain untuk pertanian lahan dapat dimanfaatkan untuk berbagai keperluan, antara lain untuk pemukiman, industri, kawasan lindung dan rekreasi. Pembuatan bata dapat dikatakan sebagai pemanfaatan lahan dalam bidang industri, yaitu dengan adanya penggalian sumber daya lahan untuk menghasilkan barang tertentu. Dalam hal ini tanah merupakan sumber daya lahan yang digunakan untuk keperluan yang berbeda, yaitu dalam pertanian dan industri yang nantinya setelah penggalian tetap dimanfaatkan sebagai lahan pertanian atau tidak. Oleh sebab itu keadaan tanah menjadi prioritas utama dalam masalah ini.

Kegiatan penggalian dapat mempengaruhi lahan pertanian yang ada. Perubahan penggunaan lahan dapat berakibat berubahnya kesuburan tanah baik secara fisik, kimia maupun biologi yang akan menentukan keberhasilan produksi pertanian (Syukur dan Nur Indah, 2006). Untuk mengatasi hal itu diperlukan suatu reklamasi lahan yang dapat mendukung terlaksananya suatu perbaikan lahan yang mengalami kerusakan sebagai akibat dari penurunan kualitas sifat-sifat tanah setelah dilakukannya penambangan tanah untuk bahan baku industri bata (Resman, 2011). Selain untuk pertanian, lahan dapat dimanfaatkan 


\section{Jurnal Tanah dan Sumberdaya Lahan Vol 7 No 1 : 159-166, 2020 \\ e-ISSN:2549-9793, doi: 10.21776/ub.jts1.2020.007.1.20}

untuk berbagai keperluan, antara lain untuk pemukiman, industri, kawasan lindung dan rekreasi. Pembuatan bata dapat dikatakan sebagai pemanfaatan lahan dalam bidang industri, yaitu dengan adanya penggalian sumber daya lahan untuk menghasilkan barang tertentu. Dalam hal ini tanah merupakan sumber daya lahan yang digunakan untuk keperluan yang berbeda, yaitu dalam pertanian dan industri yang nantinya setelah penggalian tetap dimanfaatkan sebagai lahan pertanian atau tidak. Oleh sebab itu keadaan tanah menjadi prioritas utama dalam masalah yang ada pada penelitian ini. Sebelum melakukan suatu reklamasi tanah bekas penambangan diperlukan pengetahuan mengenai morfologi tanah yang dapat mendukung kegiatan penelitian yang mengarah pada reklamasi lahan. Dengan dilaksanakannya penelitian ini diharapakan akan diketahui perubahanperubahan sifat morfologi dan sifat fisik tanah akibat penambangan tanah untuk bahan baku pembuatan batu bata dan jangka waktu pengelolaan tanah sesudahnya. Hasil penelitian ini diharapkan dapat digunakan untuk bahan pertimbangan dalam reklamasi lahan.

\section{Metode Penelitian}

Kegiatan penelitian dilakukan di lahan tegalan yang merupakan lahan bekas tambang tanah untuk pembuatan batu bata di daerah Pagak Kedung Winangun Klirong Kabupaten Kebumen. Penentuan titik-titik pembuatan profil, berdasarkan lamanya tanah sudah ditambang dan ditinggalkan serta adanya kontrol yakni : Tanah yang tidak ditambang atau belum pernah ditambang, tanah yang sudah ditambang dan ditinggalkan selama lebih dari 10 tahun, tanah yang sudah ditambang dan ditinggalkan selama \pm 5 tahun, dan tanah yang sudah ditambang dan ditinggalkan antara 1-3 tahun. Bahan dan alat yang dipersiapkan yaitu peta geologi, kompas, klinometer, cangkul, pisau, meteran, palu pedologi, kantong plastik, ring sampel, kertas label, karung, kamera dan alat tulis sedangkan untuk bahan yaitu sampel tanah dari masing-masing profil. Pemerian ciri morfologi pada setiap profil tanah menggunakan acuan boring log. Pemerian profil meliputi : tebal solum, batas horison, warna, tekstur, struktur, konsistensi, dan sebagainya pada tiap-tiap jeluk tanah. Pengambilan contoh tanah pada masing-masing jeluk pada setiap profil tanah.

Metode yang digunakan dalam penelitian ini adalah pengamatan profil lengkap (penampang tanah) yang bertujuan untuk mengumpulkan data primer yang langsung melalui pengamatan lapangan dan pemerian individu horison tanah. Pelaksanaan penelitian ini meliputi tiga tahap yaitu survei, pemerian profil tanah, pengambilan cuplikan tanah dari lahan tegalan yang belum ditambang dan sudah ditambang untuk analisis laboratorium pada jeluk tanah $0-10 \mathrm{~cm}, 10-30 \mathrm{~cm}, 30-50 \mathrm{~cm}$, dan 50-80 cm untuk masing-masing profil tanah dan analisis laboratorium. Pengambilan tanah yang dilakukan dengan cara pengambilan antar jeluk dimaksudkan untuk mengetahui adanya perkembangan tanah yang mengalami perubahan morfologi dan sifat fisika tanah akibat penambangan dari lapisan teratas sampai lapisan di bawahnya.

\section{Hasil dan Pembahasan}

Morfologi tanah dapat diartikan sifat-sifat tanah yang dapat diamati dan dipelajari di lapangan. Menurut Darmawidjaja (1970), ciriciri morfologi tanah merupakan petunjuk dari proses-proses yang telah dialami sesuatu jenis tanah selama pelapukan dan perkembangannya. Dari hal itu dapat dikatakan bahwa pengamatan tanah sebaiknya dilakukan pada profil tanah yang baru dibuat. Pengamatan tanah di lapangan ini biasanya dimulai dengan membedakan lapisan-lapisan tanah atau horison-horison (Hardjowigeno, 1993).

Terkait dengan pengamatan horison tanah pasti tidak lepas dengan istilah profil tanah. Profil tanah merupakan penampang melintang (vertikal) tanah yang terdiri dari lapisan tanah (solum) dan lapisan bahan induk. Pelaksanaan pemerian profil tanah di lapangan pada hakikatnya merupakan pengkaiian secara teliti terhadap horison tanah. Profil tubuh tanah yang telah berkembang akan memperlihatkan sejumlah horison yang tersusun dari atas ke bawah. Secara genetis horison atas merupakan horison dengan tingkat perkembangan paling lanjut dan semakin berkurang. Pemerian profil 


\section{Jurnal Tanah dan Sumberdaya Lahan Vol 7 No 1 : 159-166, 2020 \\ e-ISSN:2549-9793, doi: 10.21776/ub.jts1.2020.007.1.20}

tanah ini merupakan metode baku untuk mengetahui sejumlah watak tanah. Pemerian horison-horison tanah di lapangan umumnya berdasarkan pada sejumlah watak tanah yang digunakan sebagai faktor-faktor pembeda antara lain: warna tanah, struktur, konsistensi, perakaran, batas horison. Adapun yang paling penting dalam pemerian ini adalah batas-batas tiap horison, ketebalan horison, dan topografi permukaan tanah.

Tanah mendapatkan warnanya dari berbagai sumber. Pada penelitian yang dilakukan pada tanah Inceptisol yang sudah ditambang maupun yang belum ditambang didapatkan warna tanah berupa coklat gelap, coklat kekelabuan sangat gelap, sampai coklat kekuningan yaitu berkisar 10 YR 3/2 sampai 10 YR 5/6. Menurut penelitian yang dilakukan di lahan karst Gunung Kidul (Taharu, 2006) didapatkan warna tanah dari coklat sampai coklat kekuningan gelap yaitu berkisar 7,5 YR 4/4 sampai 10 YR 4/6. Selain itu pada tanah tersebut juga terdapat warna yang gelap, hal ini akibat dari kandungan bahan organik tanah. Berdasarkan faktor-faktor yang mempengaruhi warna tanah ini dapat diketahui bahwa tanah yang ditambang lagi dan ditinggalkan bertahuntahun dapat berubah warna seiring dengan kerusakan profil tanah yang terjadi akibat penambangan tanah tersebut.

Semakin coklat warna tanah umumnya menunjukkan tinginya kandungan geotit, dan semakin merah warna tanah semakin tinggi kandungan hematit (Sembiring et al., 2013). Tanah yang tidak ditambang cenderung memiliki warna coklat kekuningan pada horizon di atasnya. Warna coklat kekuningan menunjukkan kandungan bahan orgnaik yang lebih tinggi daripada horizon terbawah. Warna tanah cenderung gelap karena kandungan bahan organik, selain ini dipengaruhi oleh bahan induk tanah berupa batuan basal yang banyak mengandung mineral primer berwarna gelap yaitu piroksin, keragaman warn tanah secara vertikal (Rajamuddin et al., 2006; Rajamuddin, 2014). Hasil pengamatan lapangan yang dilakukan pada tanah yang ditambang untuk bahan dasar pembuatan batu bata disajikan pada Tabel 1 dan 2. Struktur tanah pada keempat profil menghasilkan struktur tanah yang remah, granuler, dan sub angular blocky. Struktur tanah yang remah ada pada tanah Inceptisol yang belum pernah ditambang. Hal ini menjelaskan bahwa struktur tanah yang belum pernah ditambang disebabkan oleh adanya pengaruh dari kandungan bahan organik sedangkan pada tanah yang sudah pernah ditambang struktur tanahnya granuler sampai sub angular blocky. Hal ini disebabkan tanah tersebut mengalami penurunan bahan organik sebagai akibat telah dilakukannya penambangan tanah selama bertahun-tahun. Selain itu juga kemungkinan disebabkan oleh adanya percampuran antara pasir dan lempung yang dilakukan untuk penambangan tanah untuk bahan dasar pembuatan batu bata sehingga tanah yang telah dilakukan penambangan untuk bahan dasar pembuatan batu bata mengalami penurunan kualitas struktur tanah yang signifikan.

Konsistensi tanah dapat dikatakan sebagai tingkat kelekatan tanah terhadap benda lain. Konsistensi tanah di lapangan ditentukan dalam kondisi basah dan lembab (Sembiring et al., 2013). Pada profil tanah yang tidak ditambang termasuk konsistensi gembur dan sedikit lekat, hal ini disebabkan pada tanah tersebut kandungan bahan organiknya masih tinggi, sehingga menghasilkan tanah yang gembur. Untuk profil tanah yang telah ditambang dan ditinggalkan konsistensinya termasuk konsistensi lepas-lepas. Hal ini karena dilakukannya penambangan tanah untuk bahan dasar batu bata yang menyebabkan kandungan bahan organik tanah menjadi menurun serta mengurangi vegetasi yang tumbuh di atas tanah tersebut. Hasil pengamatan lapangan yang disajikan pada Tabel 1 dan 2 menunjukkan bahwa profil tanah yang tidak ditambang pada setiap jeluk terdapat perakaran dengan melihat keadaan ini dapat diketahui bahwa tanah Inceptisol memiliki tingkat kesuburan yang baik. Akan tetapi dari pengamatan untuk profil tanah yang telah ditambang dan ditinggalkan untuk bahan dasar pembuatan batu bata zona perakarannya relatif sedikit sampai tidak ada. Hal ini diduga bahwa tanah yang telah ditambang kurang mendapatkan suplai dari vegetasi pada bagian atas tanah sehingga mengalami penurunan kesuburan tanah yang sangat signifikan yang berdampak pada penurunan kualitas dari tanah itu sendiri. 
Jurnal Tanah dan Sumberdaya Lahan Vol 7 No 1 : 159-166, 2020

e-ISSN:2549-9793, doi: 10.21776/ub.jts1.2020.007.1.20

Tabel 1. Morfologi tanah Inceptisol yang tidak ditambang serta ditambang dan ditinggalkan $>10$ tahun pada daerah Pagak Kedung Winangun Klirong, Kabupaten Kebumen.

\begin{tabular}{|c|c|c|c|c|c|c|c|c|c|}
\hline \multirow[t]{3}{*}{ No. } & \multirow[t]{3}{*}{ Paramater } & \multicolumn{4}{|c|}{ Tanah yang tidak ditambang } & \multicolumn{4}{|c|}{ Tanah yang ditambang dan ditinggalkan $>10$ tahun } \\
\hline & & \multicolumn{4}{|c|}{ Jeluk $(\mathrm{cm})$} & \multicolumn{4}{|c|}{ Jeluk $(\mathrm{cm})$} \\
\hline & & 0-10 & $10-30$ & $30-50$ & $50-80$ & 0-10 & $10-30$ & $30-50$ & $50-80$ \\
\hline 1 & Warna & $\begin{array}{c}\text { Coklat } \\
\text { gelap } \\
10 \text { YR 3/3 }\end{array}$ & $\begin{array}{c}\text { Coklat } \\
\text { kekuningan } \\
\text { gelap } \\
10 \text { YR 4/4 }\end{array}$ & $\begin{array}{c}\text { Coklat } \\
\text { kekuningan } \\
\text { gelap } \\
10 \text { YR 4/4 }\end{array}$ & $\begin{array}{c}\text { Coklat } \\
\text { kekuningan } \\
\text { gelap } \\
10 \text { YR 3/4 }\end{array}$ & $\begin{array}{c}\text { Coklat } \\
\text { kekelabuan } \\
\text { sangat gelap } \\
10 \text { YR 3/2 }\end{array}$ & $\begin{array}{c}\text { Coklat } \\
\text { gelap } \\
10 \mathrm{YR} \mathrm{3/3}\end{array}$ & $\begin{array}{c}\text { Coklat } \\
\text { kekuningan } \\
\text { gelap } \\
10 \text { YR 4/4 }\end{array}$ & $\begin{array}{c}\text { Coklat } \\
\text { kekuningan } \\
\text { gelap } \\
10 \mathrm{YR} 3 / 4\end{array}$ \\
\hline 2 & Struktur & Remah & Remah & Remah & Remah & Granuler & Granuler & Granuler & Granuler \\
\hline 3 & Konsistensi & Gembur & Gembur & Gembur & Gembur & Lepas-lepas & Lepas-lepas & Lepas-lepas & Lepas-lepas \\
\hline 4 & Perakaran & Banyak & Sedang & Sedikit & Sedikit & Sedikit & Sedikit & Tidak ada & Tidak ada \\
\hline 5 & $\begin{array}{l}\text { Batas } \\
\text { Horison }\end{array}$ & Berangsur & Berangsur & Berangsur & Berangsur & Samar & Samar & Samar & Samar \\
\hline
\end{tabular}


Jurnal Tanah dan Sumberdaya Lahan Vol 7 No 1 : 159-166, 2020

e-ISSN:2549-9793, doi: 10.21776/ub.jts1.2020.007.1.20

Tabel 2. Morfologi tanah Inceptisol yang ditambang dan ditinggalkan \pm 5 tahun serta ditambang dan ditinggalkan \pm 1-3 tahun pada daerah Pagak Kedung Winangun Klirong Kabupaten Kebumen.

\begin{tabular}{|c|c|c|c|c|c|c|c|c|c|}
\hline \multirow[t]{3}{*}{ No } & \multirow[t]{3}{*}{ Paramater } & \multicolumn{4}{|c|}{ Tanah yang ditambang dan ditinggalkan \pm 5 tahun } & \multicolumn{4}{|c|}{ Tanah yang ditambang dan ditinggalkan $\pm 1-3$ tahun } \\
\hline & & \multicolumn{4}{|c|}{ Jeluk $(\mathrm{cm})$} & \multicolumn{4}{|c|}{ Jeluk $(\mathrm{cm})$} \\
\hline & & 0-10 & $10-30$ & $30-50$ & $50-80$ & 0-10 & $10-30$ & $30-50$ & $50-80$ \\
\hline 1 & Warna & $\begin{array}{c}\text { Coklat } \\
\text { kekuningan } \\
\text { gelap } \\
10 \text { YR 3/4 }\end{array}$ & $\begin{array}{c}\text { Coklat } \\
\text { kekuningan } \\
\text { gelap } \\
10 \text { YR 3/4 }\end{array}$ & $\begin{array}{c}\text { Coklat } \\
\text { gelap } \\
10 \mathrm{YR} \mathrm{3/3}\end{array}$ & $\begin{array}{c}\text { Coklat } \\
\text { kekuningan } \\
\text { gelap } \\
10 \text { YR 3/4 }\end{array}$ & $\begin{array}{c}\text { Coklat } \\
\text { kekelabuan } \\
\text { sangat gelap } \\
10 \text { YR 3/2 }\end{array}$ & $\begin{array}{c}\text { Coklat } \\
\text { gelap } \\
10 \text { YR 3/3 }\end{array}$ & $\begin{array}{c}\text { Coklat } \\
\text { kekuningan } \\
10 \text { YR 5/4 }\end{array}$ & $\begin{array}{c}\text { Coklat } \\
\text { kekuningan } \\
10 \text { YR 5/6 }\end{array}$ \\
\hline 2 & Struktur & Granuler & Granuler & Granuler & Granuler & Granuler & Granuler & $\begin{array}{c}\text { Subangular } \\
\text { blocky }\end{array}$ & $\begin{array}{c}\text { Subangular } \\
\text { blocky }\end{array}$ \\
\hline 3 & Konsistensi & Lepas-lepas & Lepas-lepas & Lepas-lepas & Lepas-lepas & Lepas-lepas & Lepas-lepas & Lepas-lepas & Lepas-lepas \\
\hline 4 & Perakaran & Sedikit & Sedikit & Tidak ada & Tidak ada & Sedikit & Sedikit & Tidak ada & Tidak ada \\
\hline 5 & $\begin{array}{l}\text { Batas } \\
\text { Horison }\end{array}$ & Samar & Samar & Samar & Samar & Samar & Samar & Berangsur & Berangsur \\
\hline
\end{tabular}


Jurnal Tanah dan Sumberdaya Lahan Vol 7 No 1 : 159-166, 2020

e-ISSN:2549-9793, doi: 10.21776/ub.jts1.2020.007.1.20

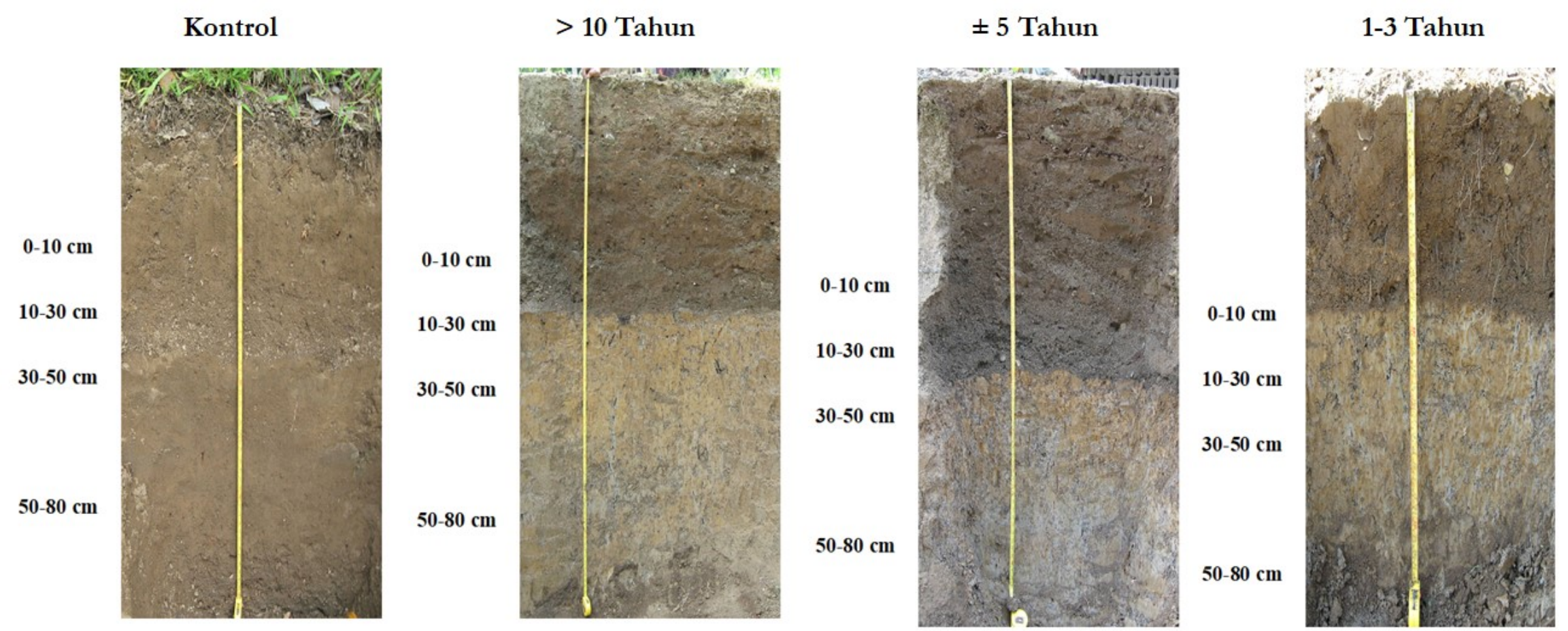

Gambar 1. Tanah Inceptisol setelah ditambang untuk bahan baku pembuatan batu bata. 


\section{Jurnal Tanah dan Sumberdaya Lahan Vol 7 No 1 : 159-166, 2020 \\ e-ISSN:2549-9793, doi: 10.21776/ub.jts1.2020.007.1.20}

Pada penelitian yang dilakukan pada tanah Inceptisol yang ada pada toposekuen lereng selatan Gunung Merapi (Resman, 2006) diketahui bahwa tanah Inceptisol memiliki batas horison yang rata dan jelas serta ada juga batas horison yang bergelombang tidak jelas. Hal ini karena daerah tersebut memang berada di lereng gunung. Lain halnya dengan hasil pengamatan lapangan pada tanah Inceptisol yang telah ditambang dan tanah yang sudah ditambang, batas horison dari keempat profil tanah menunjukkan batas horison yang samar sampai berangsur dengan bentuk horison tidak teratur dan tidak jelas (Tabel 1 dan 2). Hal ini menunjukkan bahwa tanah Inceptisol terletak pada topografi yang tidak rata dan bergelombang. Selain itu diduga ada penyebab lain untuk batas tanah yang sudah ditambang dan ditinggalkan bertahun-tahun yaitu adanya pengalian tanah yang cukup intensif sehingga tanah menjadi tidak jelas batasnya.

\section{Kesimpulan}

Dibandoingkan dengan tanah yang tidak ditambang untuk bahan dasar batu bata, tanah Inceptisol yang telah ditambang untuk bahan dasar batu bata mengalami perubahan morfologi. Warna tanah berubah dari coklat gelap dan coklat kekuningan menjadi coklat kelam sampai coklat kekuningan; menunjukkan kandungan bahan organik yang lebih tinggi daripada horizon di bawahnya. Struktur tanah berubah dari struktur yang remah menjadi granuler sampai sub angular blocky; menunjukkan bahwa tanah yang sudah ditambang bertahuntahun mengalami penurunan bahan organik. Konsistensi tanah berubah dari gembur menjadi lepas-lepas kemungkinan hal ini disebabkan kandungan bahan organik tanah menjadi menurun serta mengurangi vegetasi yang tumbuh diatas tanah tersebut. Zona perakaran tanah berubah dari perakaran yang banyak menjadi zona perakaran yang relatif sedikit; kemungkinan disebabkan kurang mendapatkan suplai dari vegetasi pada bagian atas tanah sehingga mengalami penurunan kesuburan tanah yang sangat signifikan. Tanah Inceptisol terletak pada topografi yang rata dan bergelombang. Adanya penggalian tanah yang cukup intensif sehingga batas horizon tanah menjadi tidak jelas.

\section{Ucapan Terima Kasih}

Penulis mengucapkan terima kasih kepada Kepala Badan Penelitian dan Pengembangan Daerah Provinsi Sumatera Selatan yang telah memberikan kesempatan dalam mengikuti Workshop Penulisan Karya Tulis Ilmiah sehingga penulis bisa ikut berpartisipasi dalam kegatan dan dapat menulis artikel yang diterbitkan dalam jurnal ini. Terima kasih juga penulis sampaikan kepada rekan-rekan peneliti yang telah membantu penelitian ini.

\section{Daftar Pustaka}

Darmawidjaja, M.Isa. 1970. Azas-Azas Klasifikasi Tanah. RRC-Getas. Getas.

Hardjowigeno, S. 1992. Ilmu Tanah. Mediyatama Sarana Perkasa. Jakarta.

Rajamuddin, U.A. dan Sanusi, I. 2014. Karakteristik morfologi dan klasifikasi tanah inceptisol pada beberapa sistem lahan di Kabupaten Jeneponto Sulawesi Selatan. Jurnal Agroland 21(2): 81-85.

Rajamuddin, U.A., Syamsul. A.S. dan Radjagukguk, B. 2006. Karakteristik kimiawi dan mineralogi tanah pada beberapa ekosistem bentang lahan karst di Kabupaten Gunung Kidul. Jurnal Ilmu Tanah dan Lingkungan 6: 1-12.

Resman. 2006. Kajian Beberapa Sifat Kimia dan Fisika Inceptisol Pada Toposekuen Lereng Selatan Gunung Merapi Kabupaten Sleman. Fakultas Pertanian. Universitas Gadjah Mada. Tesis.

Resman. 2011. Morfologi dan karakteristik tanah di Pugeran, Yogyakarta. Jurnal Agroteknos 1(2): 102-106.

Sembiring, M., Ridwandi, dan Mukhlis. 2013. Morfologi dan klasifikasi tanah lereng utara Gunung Sinabung Kabupaten Karo Sumatera Utara. Jurnal Online Agroteknologi 2(1): 324332.

Syukur, A. dan Nur Indah, M. 2006. Kajian pengaruh pemberian macam pupuk organik terhadap pertumbuhan dan hasil tanaman jahe di Inceptisol, Karanganyar. Jurnal Ilmu Tanah dan Lingkungan 6: 124-131.

Taharu. 2006. Karakterisik dan Genesis Tanah yang Berkembang Pada Beberapa Tipe Bentang Lahan Karst Gunung Kidul. Fakultas Pertanian. Universitas Gadjah Mada. Tesis. 
halaman ini sengaja dikosongkan 